Syntax Literate: Jurnal Ilmiah Indonesia p-ISSN: 2541-0849 e-ISSN : 2548-1398

Vol. 6, Spesial Issue No. 1, November 2021

\title{
PENGARUH PERENCANAAN PAJAK, STRUKTUR MODAL, DAN UKURAN PERUSAHAAN TERHADAP NILAI PERUSAHAAN PADA PERUSAHAAN YANG TERDAFTAR DI BURSA EFEK INDONESIA
}

\author{
Novi Endri Astuti, Moeljadi, Erna Hernawati \\ Universitas Pembangunan Nasional (UPN) Veteran Jakarta, Universitas Brawijaya \\ (UNBRAW) Indonesia \\ Email: novien0211@gmail.com,moeljadip@yahoo.com,erna.hernawati@upnvj.ac.id
}

\begin{abstract}
Abstrak
Penelitian ini bertujuan untuk mengetahui pengaruh perencanaan pajak, struktur modal, dan ukuran perusahaan terhadap nilai perusahaan pada perusahaan LQ45. Populasi dalam penelitian ini adalah perusahaan dalam Indeks LQ45 di Bursa Efek Indonesia antara tahun 2017-2019. Data yang digunakan dalam penelitian ini adalah laporan keuangan dan data harga pasar saham yang diperoleh dari BEI. Sampel yang digunakan sebanyak 28 perusahaan yang dipilih melalui metode purposive sampling. Penelitian ini menggunakan metode regresi data panel dan menggunakan Eviews versi 10 untuk pengolahannya. Hasil pengujian menunjukkan bahwa perencanaan pajak dan struktur modal tidak mempengaruhi nilai perusahaan, sedangkan ukuran perusahaan mempunyai pengaruh negative pada nilai perusahaan.
\end{abstract}

Kata Kunci: nilai perusahaan; perencanaan pajak; struktur modal; ukuran perusahaan

\section{Abstract}

This study aims to determine the effect of tax planning, capital structure, and firm size on firm value at LQ45 company. The population of this research is companies in the LQ45 Index on the Indonesia Stock Exchange between 2017-2019. The data used in this study are financial reports, stock market price data obtained from the IDX. The sample used is 28 companies selected through purposive sampling method. This research uses panel data regression method and uses Eviews version 10 for processing. The test results show that tax planning and capital structure do not affect firm value, while firm size has a negative effect on firm value.

Keywords: firm value; tax planning; capital structure; firm size

Received: 2021-10-20; Accepted: 2021-11-05; Published: 2021-11-18

\section{Pendahuluan}

Pada awal bulan Maret 2020 pemerintah secara resmi mengumumkan adanya pasien Covid-19 di Indonesia. Pemerintah menerapkan beberapa cara untuk mencegah penularan Covid-19, salah satunya adalah membatasi orang untuk keluar rumah. Hal ini

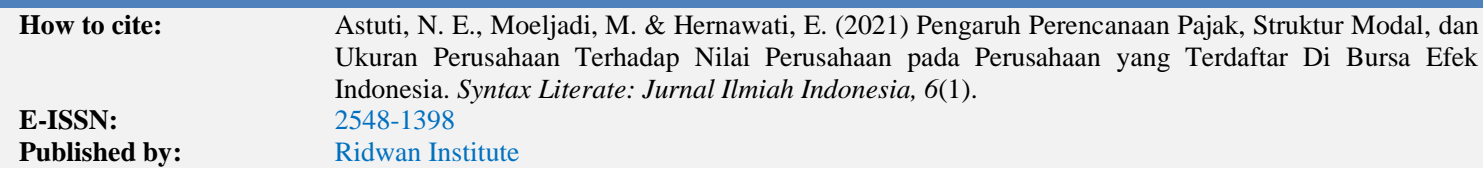


tentu memukul sektor perekonomian. Di bulan Maret 2020 IHSG mengalami penurunan paling signifikan, tetapi bersamaan dengan bertambahnya kasus Covid-19, IHSG terus mengalami peningkatan. Salah satu penggerak IHSG adalah indeks LQ45 yang berisi perusahaan yang sahamnya paling likuid dan mempunyai prospek yang bagus di masa depan.

Keuntungan yang diharapkan investor pada saat membeli saham adalah dividen dan capital gain. Tetapi di samping keuntungan potensi kerugian juga sama besarnya. Investor akan mempertimbangkan banyak hal untuk mengurangi risiko kerugian yang dihadapi ketika akan membeli saham. Investor hanya akan membeli saham ketika yakin bahwa nilai perusahaan akan naik di masa mendatang. Indeks harga saham LQ45 yang terus naik menunjukkan bahwa saham LQ45 diapresiasi dengan baik oleh investor karena dianggap bahwa saham LQ45 mempunyai nilai. Nilai perusahaan diindikasikan dengan harga saham, jika nilai perusahaan meningkat menyebabkan harga saham akan meningkat juga (Sudana, 2015). Faktor internal maupun eksternal perusahaan mempengaruhi nilai saham. Beberapa faktor yang ingin diteliti oleh penulis adalah perencanaan pajak, struktur modal dan ukuran perusahaan.

Perencanaan pajak merupakan suatu tindakan untuk mengurangi jumlah pajak yang harus dibayarkan. Perencanaan pajak tidak selalu berpengaruh pada nilai perusahaan dibuktikan oleh penelitian yang dilakukan (Yuliem, 2018). Tetapi (Santana \& Rezende, 2016) dan (Kirkpatrick \& Radicic, 2020) berpendapat bahwa perencanaan pajak mempengaruhi secara negatif nilai perusahaan.

Struktur modal adalah struktur pendanaan perusahaan yang berada di sisi pasiva neraca yang terdiri dari utang dan ekuitas. Struktur modal biasa digambarkan dengan debt to equity ratio (DER). Jika nilai DER lebih dari 1 maka pembiayaan dari utang lebih banyak daripada dari ekuitas. Menurut pecking order theory, pilihan pendanaan perusahaan pertama akan dipilih adalah internal perusahaan yaitu dari laba ditahan karena tidak ada biaya yang harus dikeluarkan. Pilihan yang kedua adalah dari eksternal perusahaan yaitu dari utang karena biaya utang yaitu biaya bunga pinjaman dapat dibiayakan baik secara komersial maupun secara fiskal. Pilihan terakhir pendanaan adalah penerbitan saham baru, karena biaya saham yaitu dividen tidak dapat dibiayakan. (Chasanah \& Adhi, 2018) menunjukkan bahwa struktur modal tidak berpengaruh signifikan terhadap nilai perusahaan, sedangkan (Lestari, 2017) menunjukkan bahwa struktur modal tidak berpengaruh signifikan terhadap nilai perusahaan. (Kusumawati \& Rosady, 2018), (Fajilet \& Santioso, n.d.), (Tondok, Pahlevi, \& Aswan, 2019), (Ramdhonah, Solikin, \& Sari, 2019) mengemukakan hasil yang berbeda, yang menunjukkan bahwa struktur modal berdampak positif terhadap nilai perusahaan.

Menurut (Riyanto, 2011), ukuran perusahaan berasal dari nilai ekuitas, nilai penjualan, atau nilai aset. Semakin besar nilai perusahaan maka semakin aman bagi investor untuk menanamkan dananya. Selain itu, seiring dengan ekspansi perusahaan, perusahaan akan lebih mudah mendapatkan pendanaan. (Kusna \& Setijani, 2018) mengemukakan bahwa besar kecilnya suatu perusahaan diwakili oleh total aset yang dimiliki oleh perusahaan tersebut. Menurut (Pratama, 2019), semakin besar perusahaan 
maka semakin besar pula aset yang dimiliki, sehingga untuk mempertahankan kegiatan operasionalnya dibutuhkan modal yang lebih banyak. (Kusna \& Setijani, 2018), (Rajagukguk, Ariesta, \& Pakpahan, 2019), (Usman, 2020), (Nirmala, Moeljadi, \& Andarwati, 2016), (Wahyudi, Chuzaimah, \& Sugiarti, 2016), dan (Hasnawati \& Sawir, 2015) melakukan penelitian yang menunjukkan hasil pengaruh positif antara ukuran perusahaan dengan nilai perusahaan. Penelitian dengan hasil yang berlawanan dilakukan oleh (Ramdhonah et al., 2019), dan (Abdullah, Syariati, \& Hamid, 2017) yang menunjukkan pengaruh negatif ukuran perusahaan terhadap nilai perusahaan. Sedangkan (Chasanah \& Adhi, 2018) menyatakan tidak ada pengaruh antara ukuran perusahaan terhadap nilai perusahaan.

\section{Metode Penelitian}

\section{Definisi Operasional}

\section{1) Nilai Perusahaan}

Nilai perusahaan adalah harga saham yang mencerminkan kinerja perusahaan yang dibentuk oleh penawaran dan permintaan di pasar modal yang mencerminkan penilaian masyarakat terhadap kinerja perusahaan (Rizqi, Harmono, \& Nugroho, 2016). Pengukurannya menggunakan price to book value (PBV) dengan rumus sebagai berikut:

$$
P B V=\frac{\text { Harga Per Lembar Saham }}{\text { Nilai Buku Per Lembar Saham }}
$$

\section{2) Perencanaan Pajak}

Perencanaan pajak merupakan penghematan pajak dengan cara memanfaatkan ketentuan perpajakan yang dilakukan secara legal untuk meminimalkan kewajiban (Pohan, 2016). Pengukurannya menggunakan effective tax rate (ETR) dengan rumus sebagai berikut:

$$
\text { ETR }=\frac{\text { Tax Paid }}{\text { Profit Before Tax }}
$$

\section{3) Struktur Modal}

Struktur modal adalah struktur pendanaan perusahaan yang diperoleh dari jumlah utang dan modal sendiri (Kusumawati \& Rosady, 2018). Dengan pengukurannya menggunakan debt to equity ratio (DER) dengan rumus sebagai berikut:

$$
\text { DER }=\frac{\text { Total Hutang }}{\text { Ekuitas }}
$$

\section{4) Ukuran Perusahaan}

Ukuran perusahaan menggambarkan besar kecilnya suatu perusahaan yang dapat dinyatakan dengan total aktiva atau total penjualan bersih. Semakin besar total aktiva maupun penjualan, maka semakin besar pula ukuran suatu perusahaan (Abdullah et al., 2017). Pengukurannya menggunakan log natural total asset yaitu sebagi berikut: 
Pengaruh Perencanaan Pajak, Struktur Modal, dan Ukuran Perusahaan terhadap Nilai Perusahaan pada Perusahaan yang Terdaftar di Bursa Efek Indonesia

\section{Ukuran Perusahaan $=\operatorname{Ln}($ Total Aset $)$}

\section{Populasi, Sampel dan Metode Penelitian}

Populasi dalam penelitian ini adalah perusahaan yang masuk dalam indeks LQ45 pada tahun 207-2019. Sampel penelitian dipilih menggunakan Teknik purposive sampling yang menghasilkan 28 perusahaan sebagai sampel penelitian. Sumber data penelitan berasal dari website idx.co.id. Teknik analisis yang digunakan adalah regresi data panel dengan menggunakan eviews version 10.

\section{Hasil dan Pembahasan}

\section{Statistik Deskriptif}

Tabel 1

Hasil Statistik Deskriptif

\begin{tabular}{lcccc}
\hline & PBV & ETR & DER & LN TOTAL ASET \\
\hline Mean & 2.166786 & 0.243810 & 1.664524 & 25.04597 \\
\hline Median & 1.720000 & 0.250000 & 0.770000 & 24.82844 \\
\hline Maximum & 8.170000 & 0.720000 & 8.870000 & 27.97939 \\
\hline Minimum & 0.570000 & 0.010000 & 0.170000 & 22.41889 \\
\hline Std. Dev. & 1.466911 & 0.12725 & 1.869148 & 1.348485 \\
\hline observations & 84 & 84 & 84 & 84 \\
\hline
\end{tabular}

Sumber: Hasil Pengolahan Data Dengan Eviews 10

Rata-rata variabel nilai perusahaan adalah 2.166786. Hal tersebut menunjukkan bahwa rata-rata harga pasar saham LQ45 yang menjadi objek penelitian adalah sebesar 2.166786 kali lipat dari harga bukunya yang artinya investor menganggap bahwa nilai perusahaan LQ45 yang menjadi objek penelitian tinggi. Rata-rata variabel perencanaan pajak adalah sebesar 0.243810. Hal tersebut menunjukkan bahwa rata-rata perusahaan yang menjadi objek penelitian membayar pajak penghasilan sebesar $24.38 \%$ dari jumlah laba sebelum pajaknya. Rata-rata variabel struktur modal adalah sebesar 1.664524. Hal tersebut menunjukkan bahwa rata-rata perusahaan yang menjadi objek penelitian mempunyai jumlah utang sebanyak 1.664524 kali lipat lebih banyak dari jumlah ekuitasnya. Rata-rata variabel ukuran perusahaan adalah sebesar 24.96038 .

\section{Metode Analisis Regresi Data Panel}

Tabel 2

Uji Chow (Common Effect Model vs Fixed Effect Model)

\begin{tabular}{llll}
\hline Effects Test & Statistic & d.f. & Prob. \\
\hline Cross-section F & 20.522794 & $(27,53)$ & 0.0000 \\
\hline Cross-section Chi-square & 204.827872 & 27 & 0.0000 \\
\hline
\end{tabular}

Sumber: Hasil olah data menggunakan eviews version 10 
Berdasarkan tabel di atas, nilai probabilitas Cross-section Chi-square adalah sebesar $0.0000<0.05$ sehingga $\mathrm{H} 0$ ditolak dan $\mathrm{H} 1$ diterima, artinya fixed effect model (FEM) lebih baik digunakan dalam penelitian daripada common effect model (CEM).

\section{Tabel 3}

Uji Hausman (Fixed Effect Model vs Common Effect Model)

\begin{tabular}{llll}
\hline & Chi-Sq. & & \\
Test Summary & Statistic & Chi-Sq. d.f. Prob. \\
\hline Cross-section random & 11.886769 & 3 & 0.0078 \\
\hline
\end{tabular}

Sumber: Hasil olah data menggunakan eviews version 10

Berdasarkan tabel 3, nilai probabilitas Cross-section random adalah sebesar $0.0078<0.05$ sehingga $\mathrm{H} 1$ diterima dan $\mathrm{H} 0$ ditolak, artinya fixed effect model (FEM) lebih baik digunakan dalam penelitian daripada random effect model (REM) dan tidak perlu dilakukan uji Lagrange Multiplier.

\section{Persamaan Regresi Data Panel}

\section{Tabel 4}

Fixed Effect Model

\begin{tabular}{lllll}
\hline Variable & \multicolumn{2}{l}{ Coefficient Std. Error } & t-Statistic & Prob. \\
\hline $\mathrm{C}$ & 61.79616 & 15.70859 & 3.933909 & 0.0002 \\
\hline $\mathrm{X} 1$ & -0.330956 & 0.917623 & -0.360667 & 0.7198 \\
\hline $\mathrm{X} 2$ & 0.014067 & 0.079557 & 0.176821 & 0.8603 \\
\hline $\mathrm{X} 3$ & -2.378511 & 0.627502 & -3.790446 & 0.0004 \\
\hline
\end{tabular}

Sumber: Hasil olah data menggunakan eviews version 10

Nilai Perusahaan $=61.79616+-0.330956($ Perencanaan Pajak $)+0.014067$ (Struktur Modal) + -2.378511 (Ukuran Perusahaan)

Berdasarkan hasil uji regresi diketahui bahwa nilai konstanta adalah sebesar 61.79616, sehingga diperoleh kesimpulan bahwa jika nilai perencanaan pajak (ETR), struktur modal (DER), dan ukuran perusahaan (Ln total asset) dianggap konstan atau nol, maka nilai perusahaan (PBV) adalah senilai 61.79616.

Berdasarkan hasil uji regresi diketahui bahwa nilai konstanta adalah sebesar 61.79616, sehingga diperoleh kesimpulan bahwa jika nilai perencanaan pajak (ETR), struktur modal (DER), dan ukuran perusahaan (Ln total asset) dianggap konstan atau nol, maka nilai perusahaan (PBV) adalah senilai 61.79616.

Nilai koefisien regresi struktur modal yang diukur dengan debt to equity ratio (DER) adalah sebesar 0.014067, sehingga diperoleh kesimpulan jika nilai DER mengalami peningkatan sebesar 1 (satu) dengan asumsi bahwa koefisien variabel lain tetap, maka nilai perusahaan akan mengalami kenaikan sebesar 0.014067. Hal tersebut menunjukkan bahwa DER dan PBV memiliki hubungan positif. 
Nilai koefisien regresi ukuran perusahaan yang diukur dengan Ln total aset adalah sebesar -2.378511, sehingga diperoleh kesimpulan jika nilai Ln total aset mengalami peningkatan sebesar 1 (satu) dengan asumsi bahwa koefisien variabel lain tetap, maka nilai perusahaan akan mengalami penurunan sebesar 2.388584. Hal tersebut menunjukkan bahwa Ln total aset dan PBV memiliki hubungan negatif.

\section{Uji Hipotesis}

\section{Tabel 5}

Hasil Uji T

\begin{tabular}{lllll}
\hline Variable & \multicolumn{2}{l}{ Coefficient Std. Error } & t-Statistic & Prob. \\
\hline $\mathrm{C}$ & 61.79616 & 15.70859 & 3.933909 & 0.0002 \\
\hline $\mathrm{X} 1$ & -0.330956 & 0.917623 & -0.360667 & 0.7198 \\
\hline $\mathrm{X} 2$ & 0.014067 & 0.079557 & 0.176821 & 0.8603 \\
\hline $\mathrm{X} 3$ & -2.378511 & 0.627502 & -3.790446 & 0.0004 \\
\hline
\end{tabular}

Sumber: Hasil olah data menggunakan eviews version 10

a) Pengaruh Perencanaan Pajak (ETR) terhadap Nilai Perusahaan (PBV)

Berdasarkan hasil uji t tersebut diatas, perencanaan pajak yang diukur dengan effective tax ratio (ETR) menunjukkan nilai nilai signifikansi $\alpha$ sebesar $0.7198>$ 0.05 maka H1 ditolak. Kesimpulannya adalah variabel perencanaan pajak (ETR) tidak berpengaruh signifikan terhadap nilai perusahaan (PBV). Investor tidak terlalu memperhatikan rasio besarnya pajak yang dibayarkan dengan penghasilan sebelum pajak dikarenakan pengetahuan investor tentang pajak yang masih rendah.

b) Pengaruh Struktur Modal (DER) terhadap Nilai Perusahaan (PBV)

Berdasarkan hasil uji t di atas, struktur modal yang diukur dengan debt to equity ratio (DER) menunjukkan nilai signifikansi $\alpha$ sebesar $0.8603>0.05$ maka H1 ditolak. Kesimpulannya adalah variabel struktur modal (DER) tidak berpengaruh signifikan terhadap nilai perusahaan (PBV). Investor berpendapat bahwa perusahaan yang masuk dalam indeks LQ45 merupakan perusahaan yang dikelola secara profesional dan merupakan perusahaan yang memiliki masa depan yang bagus sehingga besar kecilnya rasio utang terhadap ekuitas tidak akan mempengaruhi keputusan investor dalam melakukan investasi.

c) Pengaruh Ukuran Perusahaan (Ln Total Aset) terhadap Nilai Perusahaan (PBV) Berdasarkan hasil uji $\mathrm{t}$ di atas, ukuran perusahaan yang diukur dengan ln total asset menunjukkan nilai signifikansi $\alpha$ sebesar $0.0004<0.05$ maka H1 diterima. Kesimpulannya adalah variabel ukuran perusahan (Ln total asset) berpengaruh signifikan terhadap nilai perusahaan (PBV). Nilai asset yang besar dianggap membutuhkan biaya yang besar juga dalam pengelolaannya sehingga investor menjadikan alasan jumlah aset besar dapat menurunkan nilai perusahaan. Investor juga menganggap bahwa aset yang dimiliki perusahaan dalam indeks 
LQ45 kurang produktif sehingga semakin besar aset akan semakin menurunkan nilai perusahaan.

\section{Tabel 6}

Hasil Uji Koefisien Determinasi (R2)

\begin{tabular}{llll}
\hline R-squared & 0.914649 & Mean dependent var & 2.166786 \\
\hline Adjusted R-squared & 0.866338 & S.D. dependent var & 1.466911 \\
\hline S.E. of regression & 0.536301 & Akaike info criterion & 1.869326 \\
\hline Sum squared resid & 15.24377 & Schwarz criterion & 2.766413 \\
\hline Log likelihood & -47.51170 & Hannan-Quinn criter. & 2.229948 \\
\hline F-statistic & 18.93228 & Durbin-Watson stat & 2.211334 \\
\hline Prob(F-statistic) & 0.000000 & & \\
\hline
\end{tabular}

Sumber: Hasil pengolahan data menggunakan eviews 10

Berdasarkan tabel diatas diketahui bahwa nilai Adjusted R-squared adalah senilai 0.866338 yang menunjukkan bahwa variabel independen yaitu perencanaan pajak, struktur modal, dan ukuran perusahaan dapat menjelaskan sebesar $86.63 \%$ terhadap total varians variabel dependennya yaitu nilai perusahaan, dan sisanya sebesar $13.37 \%$ dijelaskan oleh variabel lain yang tidak digunakan dalam penelitian ini.

\section{Kesimpulan}

Hasil pengujian terhadap variabel Perencanaan Pajak yang diukur dengan effective tax rate (ETR) menunjukkan hasil bahwa Perencanaan Pajak tidak berpengaruh secara signifikan terhadap Nilai Perusahaan pada 28 perusahaan yang menjadi sampel dalam penelitian ini.

Hasil pengujian terhadap variabel Struktur Modal yang diukur dengan debt to equity ratio (DER) menunjukkan hasil bahwa Struktur Modal tidak berpengaruh secara signifikan terhadap Nilai Perusahaan pada 28 perusahaan yang menjadi sampel dalam penelitian ini.

Hasil pengujian terhadap variabel Ukuran Perusahaan yang diukur dengan log natural total aset menunjukkan hasil bahwa Ukuran Perusahaan berpengaruh secara signifikan dan negatif terhadap Nilai Perusahaan pada 28 perusahaan yang menjadi sampel dalam penelitian ini. 
Pengaruh Perencanaan Pajak, Struktur Modal, dan Ukuran Perusahaan terhadap Nilai Perusahaan pada Perusahaan yang Terdaftar di Bursa Efek Indonesia

\section{BIBLIOGRAFI}

Abdullah, Wahidah, Syariati, Alim, \& Hamid, Reskianti. (2017). Pengaruh corporate social responsibility (CSR), ukuran perusahaan dan interest based debt (IBD) terhadap nilai perusahaan pada perusahaan manufaktur di jakarta Islamic index periode 2010-2016. Jurnal Minds: Manajemen Ide Dan Inspirasi, 4(2), 122-135. Google Scholar

Chasanah, Amalia Nur, \& Adhi, Daniel Kartika. (2018). Profitabilitas, struktur modal dan likuiditas pengaruhnya terhadap nilai perusahaan pada perusahaan real estate yang listed di BEI tahun 2012-2015. Fokus Ekonomi: Jurnal Ilmiah Ekonomi, 12(2), 109-128. Google Scholar

Fajilet, Eji, \& Santioso, Linda. (n.d.). Faktor-Faktor Yang Memengaruhi Nilai Perusahaan Dengan Capital Structure Sebagai Variabel Mediasi. Jurnal Paradigma Akuntansi, 1(3), 852-862. Google Scholar

Hasnawati, Sri, \& Sawir, Agnes. (2015). Keputusan keuangan, ukuran perusahaan, struktur kepemilikan dan nilai perusahaan publik di Indonesia. Jurnal Manajemen Dan Kewirausahaan (Journal of Management and Entrepreneurship), 17(1), 6575. Google Scholar

Kirkpatrick, Alan K., \& Radicic, Dragana. (2020). Tax Planning Activities and Firm Value: A Dynamic Panel Analysis. In Advances in Taxation. Emerald Publishing Limited. Google Scholar

Kusna, Irrofatun, \& Setijani, Erna. (2018). Analisis pengaruh kinerja keuangan, growth opportunity dan ukuran perusahaan terhadap struktur modal dan nilai perusahaan. Jurnal Manajemen Dan Kewirausahaan, 6(1), 93-102. Google Scholar

Kusumawati, Rita, \& Rosady, Irham. (2018). Pengaruh Struktur Modal dan Profitabilitas terhadap Nilai Perusahaan dengan Kepemilikan Manajerial sebagai Variabel Moderasi. Jurnal Manajemen Bisnis, 9(2), 147-160. Google Scholar

Lestari, Lestari. (2017). Pengaruh Kepemilikan Institusional Dan Struktur Modal Terhadap Nilai Perusahaan. Jurnal Riset Manajemen Dan Bisnis, 2(Manajemen), 293-306. Google Scholar

Nirmala, Aulia, Moeljadi, Moeljadi, \& Andarwati, Andarwati. (2016). Pengaruh Ukuran Perusahaan, Profitabilitas, Pertumbuhan Penjualan dan Kepemilikan Manajerial terhadap Struktur Modal dan Nilai Perusahaan Manufaktur di Indonesia (Perspektif Pecking Order Theory). Jurnal Aplikasi Manajemen, 14(3), 557-566. Google Scholar

Pohan, Chairil Anwar. (2016). Manajemen Perpajakan Strategi Perencanaan Pajak dan Bisnis, Jakarta, PT. Gramedia Pustaka Utama. Google Scholar

Pratama, Luthfi. (2019). Analisis Pembentukan Portofolio Saham Optimal 
Menggunakan Metode Single Index Model (Studi Empiris pada Saham Indeks LQ 45 di Bursa Efek Indonesia). Jurnal Ilmu Manajemen, 16(1), 48-60. Google Scholar

Rajagukguk, Lasmanita, Ariesta, Valencia, \& Pakpahan, Yunus. (2019). Analisis Pengaruh Profitabilitas, Ukuran Perusahaan, Keputusan Investasi, dan Kebijakan Utang Terhadap Nilai Perusahaan. Jurnal Inspirasi Bisnis Dan Manajemen, 3(1), 77. Google Scholar

Ramdhonah, Zahra, Solikin, Ikin, \& Sari, Maya. (2019). Pengaruh Struktur Modal, Ukuran Perusahaan, Pertumbuhan Perusahaan, Dan Profitabilitas Terhadap Nilai Perusahaan (Studi Empiris Pada Perusahaan Sektor Pertambangan Yang Terdaftar Di Bursa Efek Indonesia Tahun 2011-2017). Jurnal Riset Akuntansi Dan Keuangan, 7(1), 67-82. Google Scholar

Riyanto, Bambang. (2011). Dasar-dasar Pembelanjaan Perusahaan, Edisi keempat, Penerbit: BPFE. Yogyakarta. Google Scholar

Rizqi, Cicik Khilar, Harmono, Happy, \& Nugroho, Raditya. (2016). Pengaruh Lama Distres Kronis Terhadap Perubahan Jumlah Sel Osteoklas Pada Tulang Alveolar Tikus Sprague dawley (The Effect of Chronic Distres Duration on Osteoclast Changes in Alveolar Bone of Sprague dawley Rats). Pustaka Kesehatan, 4(1), 6167. Google Scholar

Santana, Silvio, \& Rezende, Amaury José. (2016). Corporate tax avoidance and firm value: evidence from Brazil. Available at SSRN 2803993. Google Scholar

Sudana, I. Made. (2015). Teori dan Praktik Manajemen Keuangan Perusahaan. Jakarta: Erlangga. Google Scholar

Tondok, Bernon Sampe, Pahlevi, Cepi, \& Aswan, Andi. (2019). Pengaruh Struktur Modal, Pertumbuhan Perusahaan, Ukuran Perusahaan Terhadap Profitabilitas dan Nilai Perusahan Pada Perusahaan Manufaktur Yang Terdaftar di Bursa Efek Indonesia Periode 2013-2017. Hasanuddin Journal Of Business Strategy, 1(3), 6678. Google Scholar

Usman, Timothy Onechojon. (2020). Corporate tax planning, board compensation and firm value in Nigeria. 1684903025. Google Scholar

Wahyudi, Henri Dwi, Chuzaimah, Chuzaimah, \& Sugiarti, Dani. (2016). Pengaruh Ukuran Perusahaan, Profitabilitas, Kebijakan Deviden, Dan Keputusan Investasi Terhadap Nilai Perusahaan (Studi Penggunaan Indeks LQ-45 Periode 2010-2014). Benefit: Jurnal Manajemen Dan Bisnis, 1(2), 156-164. Google Scholar

Yuliem, Marcella Lavenia. (2018). Pengaruh Perencanaan Pajak (Tax Planning) Terhadap Nilai Perusahaan (Firm Value) Pada Perusahaan Sektor Non Keuangan Yang Terdaftar Di BEI Periode 2013-2015. Calyptra, 7(1), 520-540. Google Scholar 
Pengaruh Perencanaan Pajak, Struktur Modal, dan Ukuran Perusahaan terhadap Nilai Perusahaan pada Perusahaan yang Terdaftar di Bursa Efek Indonesia

\section{Copyright holder:}

Novi Endri Astuti, Moeljadi, Erna Hernawati (2021)

First publication right:

Syntax Literate: Jurnal Ilmiah Indonesia

This article is licensed under:

(c) (i) (? 